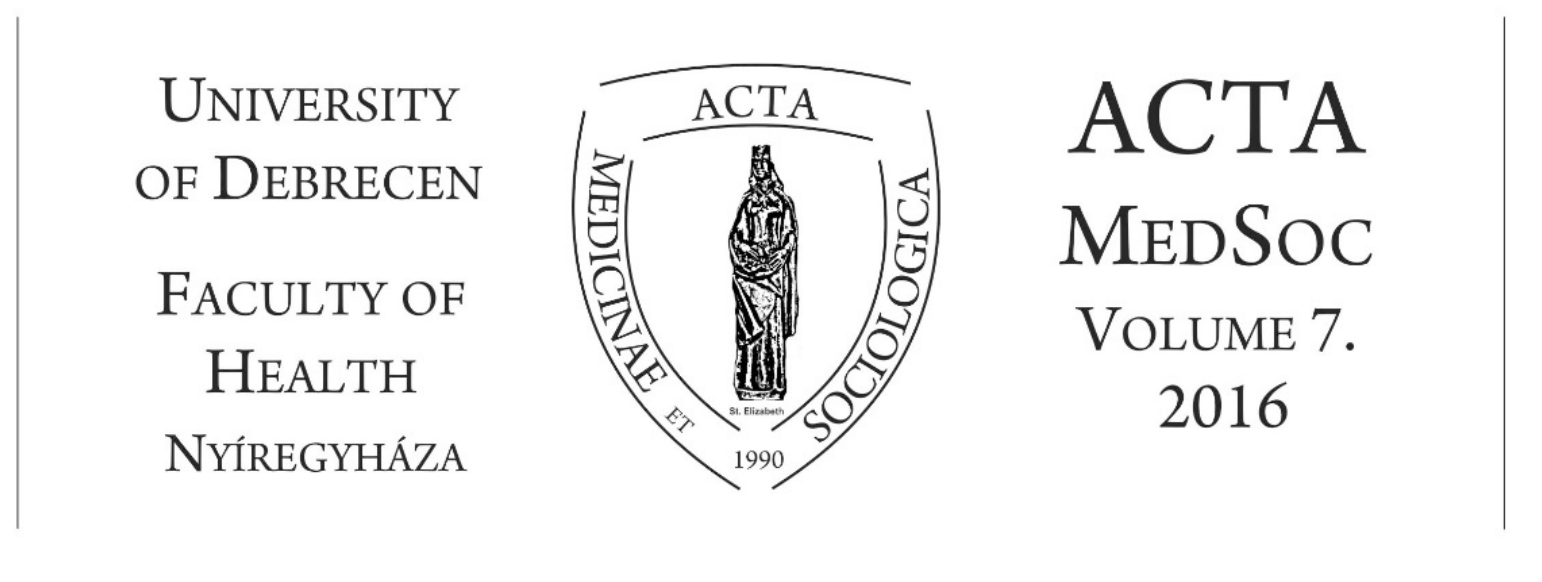

\title{
Családalapítás és gyermekvállalás a fiatalok körében
}

\section{Young People's Attitudes toward Getting Married and Having Children}

\author{
R. Fedor Anita
}

\begin{abstract}
In Hungary a very unfavourable demographic trend started in 1981 and has continued since the regime change. These changes primarily affected the relationship behaviour of couples and resulted in a transformation of family formation attitudes. Although the overall fertility rate was 1.85 in 1990, it has decreased to 1.35 today (KSH 2015). In addition, the number of marriages has dropped significantly, while the proportion of those who terminated their marriage has greatly increased.

This study maps the relationships of young people and their peculiar feelings and attitudes toward child bearing. Another goal is to investigate the thoughts and ideas of those who, due to their age or other causes, have not had children yet, and to learn more about future child bearing aspirations of those who have already had children. A part of the study tries to find an answer to the question ,If voluntary childlessness is typical of young people involved in the research, then what are the characteristics of those who chose this way of life?" Those who have difficulty conceiving a child
\end{abstract}


are asked how they feel about assisted reproductive procedures. Another major focus is to find out what young people think about marriage; whether marriage or the less restrictive cohabitation has priority in their value system.

The results show that the majority of the families prefer a two-child family model. Having three children was ranked second while one child was ranked third. The number of families who do not want any children was very small. The majority of the respondents $(55 \%)$ did not have any children at the time of the survey. Among those with children the majority have only one child but as it has been mentioned most of the young people between 15-18 and between 19-29 plan to have two children in the future. Almost half of the 15-18-year-old people plan to have the first child between the ages of 25-29. The second biggest group included those who would plan to give birth to the first child between the ages of 20 and 24 .

The majority of the recently independent young people can envision the future in marriage. Sixty-four percent of men and sixty-nine percent of women would like to get married in the future.

Keywords: attitudes child bearing, relationship form, marriage

DOI: $10.19055 /$ ams.2016.7/20-21/2

\section{Absztrakt}

Magyarországon már 1981-től igen kedvezőtlen demográfiai folyamat indult el, mely a rendszerváltozást követően tovább folytatódott. A változások a párkapcsolati magatartást és a családalapítási szokások átalakulását érintették elsősorban. Amíg 1990-ben a teljes termékenységi arányszám még 1,85 volt, addig mára 1,35-re apadt (KSH. 2015). Emellett jelentősen csökkent a házasságkötések száma, és igen számottevő a házasságot felbontók aránya.

Írásunkban a fiatalok párkapcsolati, gyermekvállalási jellemzőit térképezzük fel, továbbá célunk az is, hogy megvizsgáljuk az életkoruk és egyéb okok miatt még gyermekkel nem rendelkezők elképzeléseit és a gyermekesek további gyermekvállalási aspirációit. Ehhez kapcsolódóan arra is kitérünk, hogy jellemzö-e a vizsgálatba bekerült fiatalokra az önként vállalt gyermektelenség. Egy esetleges nehezített fogantatás esetén hogyan vélekednek az asszisztált reprodukciós eljárásokról. Kíváncsiak vagyunk arra is, vajon hogyan vélekednek a mai fiatalok a házasság intézményéről. Szívesen házasodnak vagy inkább az élettársi kapcsolat kap prioritást értékrendjükbe. Tanulmányunkban a magyar demográfiai helyzet bemutatása mellett kitérünk az Európai Unió fő́bb - a témánk szempontjából releváns - demográfiai mutatóira. A hazai általános helyzetbemutatást követően részletesen foglalkozunk a nyíregyházi fiatalok gyermekvállalási magatartásának és párkapcsolati mintázatának bemutatásával. A helyi fiatalok társadalmának 
eredményeit összevetjük az országos jellemzőkkel, melyben a „Magyar Ifjúság 2012" adatait tekintjük mérvadónak.

Eredményeink szerint a fiatalok többsége a kétgyermekes családmodellt preferálja. A második legtöbbek által ideálisnak tartott gyermekszám a három, majd harmadikként az egy gyermekben gondolkodók következnek. Elenyésző azok száma, akik nem szeretnének gyermeket. A 19-29 éves korosztály többségének (55\%) a megkérdezés pillanatában még nem volt gyermeke. A gyermekesek közül a legtöbben egyelöre egy gyermeket nevelnek, de - mint ahogyan azt említettük mind a 15-18 évesek, mind pedig a 19-29 évesek csoportján belül a legtöbben két gyermekben gondolkodnak a későbbiekben. A 15-18 évesek közel fele úgy tervezi, hogy 25-29 éves kora között vállalja az első gyermekét, az ezt követő legnépesebb csoport azoké volt, akik 20-24 éves korukra időzítenék ezt az eseményt.

A jelenleg független fiatalok meghatározó többsége házasként képzeli el a jövőjét. A férfiak 64\%-a, a nők 69\%-a szeretne házasságot kötni a jövőben.

Kulcsszavak: gyermekvállalási attitüd, párkapcsolati formák, házasodási hajlandóság

\section{Új demográfiai jellemzők ${ }^{1}$}

A posztszocialista országok új demográfiai jellemzőinek magyarázatára több megközelítési mód látott napvilágot. A téma kutatóinak egy része az értékek változásával, az új strukturális körülményekkel, a kiszámíthatatlan és bizonytalan munkaerő-piaci folyamatokkal magyarázzák a gyermekvállalási hajlandóság változását. Mások a kedvezőtlen demográfiai folyamatok okát az oktatási lehetőségek kiszélesedésében, a gyermekek napközbeni ellátását biztosító intézményrendszer elégtelenségében, a családi élet harmóniáját háttérbe szorító munkavállalási körülményekben látják (Spéder, 2006). Fentiek alapján két elméletcsoport különíthető el. Az első magyarázat a második demográfiai átmenet alapján érvel. Eszerint Nyugat-Európában már korábban (1960-as évektől) megfigyelt értékrendszer változásának átszivárgása alakította a posztszocialista országokban 1985-től kezdődően a párkapcsolatok és gyermekvállalás új mintáinak terjedését (Husz, 2006). Amíg az első demográfiai átmenet a családot, a gyermeket helyezte a középpontba, addig a második demográfiai átmenet az önmegvalósításnak, az egyén jogainak elötérbe kerülését hangsúlyozza. A jelenséget

\footnotetext{
${ }^{1}$ Az Új demográfiai jellemzők című rész az Egyensúlyban? A munkaerő-piaci karriertől a familiarizmusig címü, 2015-ben megjelent könyvünk részét képezi, amelyben részletesen foglalkozunk a nők gyermekvállalási magatartásának elemzésével, valamint a munkaerőpiaci és családi feladatok összehangolásának kérdéseivel (R. Fedor, 2015).
} 
leginkább magyarázó tényezők körülhatárolása tekintetében bár még nem alakult ki egységes álláspont, abban azonban egyetértenek a téma szakértői: „hogy ezek a tényezők szorosan kapcsolódnak az egyén posztindusztriális társadalomban betöltött, gyorsan változó szerepéhez. Ezekben a társadalmakban az egyéni életszínvonal a képzettségi szint és a képzés minőségének függvénye, de meghatározza a társadalmi célok iránti elkötelezettség mértéke, valamint az egyén önnön tehetségének felfedezésére és hasznosítására való motivációja is" (Van de Kaa, 1987:21). A második demográfiai átmenet jellemzője: a várható élettartam növekedése, a házasságkötések számának visszaesése, a válások számának növekedése, a csökkenő gyermekszám, a gyermektelenség és a házasságon kívüli születések emelkedése. A második érvelés racionális válasznak tekinti a demográfiai magatartás változását, melynek hátterében a megváltozott gazdasági helyzet húzódik meg. A posztszocialista országokban, a '90-es években a családtámogatások fokozott megvonása, a háztartások jövedelemcsökkenése a gyermekvállalás halasztását eredményezte. Továbbá, a fizetett munka világába való bekapcsolódás kiszámíthatatlansága, $\mathrm{s}$ a növekvő munkanélküliség miatt a gyermekvállalás háttérbe szorult (Husz, 2006).

Magyarországon 1991 és 1998 között egyenletesen csökkent a születések száma, s egészen 2009-ig stabilan 95-100 ezer gyermek született évente. A 2010. év végi adatok azonban felülírták ezt az így sem kedvező tendenciát. A statisztikai adatok azt mutatják, hogy 2010-ben a születések száma éppen elérte a 90 ezret. Ez több mint 6 ezerrel marad el az egy évvel korábbi újszülöttek számától. Az ezt követő év számított a totális mélypontnak, amikor is mindössze 88049 volt az élve születések száma. Jó hír azonban, hogy a 2014-es év megakasztotta ezt a csökkenő tendenciát a maga 91510 gyermekszületéssel. Bár árnyaltabb kép rajzolódik ki, ha hozzátesszük, hogy például a hat évvel korábbi mutató meghaladta a 99000 születést (KSH, 2015). A termékenység csökkenés következménye, hogy az 1990-es évek közepétől kezdve a teljes termékenységi arányszám 1,57 és 1,24 között ingadozik (Kapitány és Spéder, 2009; KSH, 2015). Ez azt jelenti, hogy a magyar lakosság nem reprodukálja saját magát, ehhez ugyanis 2,1-es termékenységi arányszám lenne szükséges. A 2013-es adatok azt mutatják, hogy hazánk Európa alacsony termékenységü országaihoz tartozik. Az Európai Unió 28 tagállamát tekintve Spanyolországban, Portugáliában, Cipruson, Görögországban, Szlovákiában és Lengyelországban rosszabbak a mutatók (Eurostat, 2013). (1. számú ábra) Hozzá kell tenni, hogy a 2009-es adatsor szerint hazánknál csak két alacsonyabb termékenységü ország volt, így mára az unión belüli helyzetünk kicsit kedvezőbb lett. 


\section{1. számú ábra}

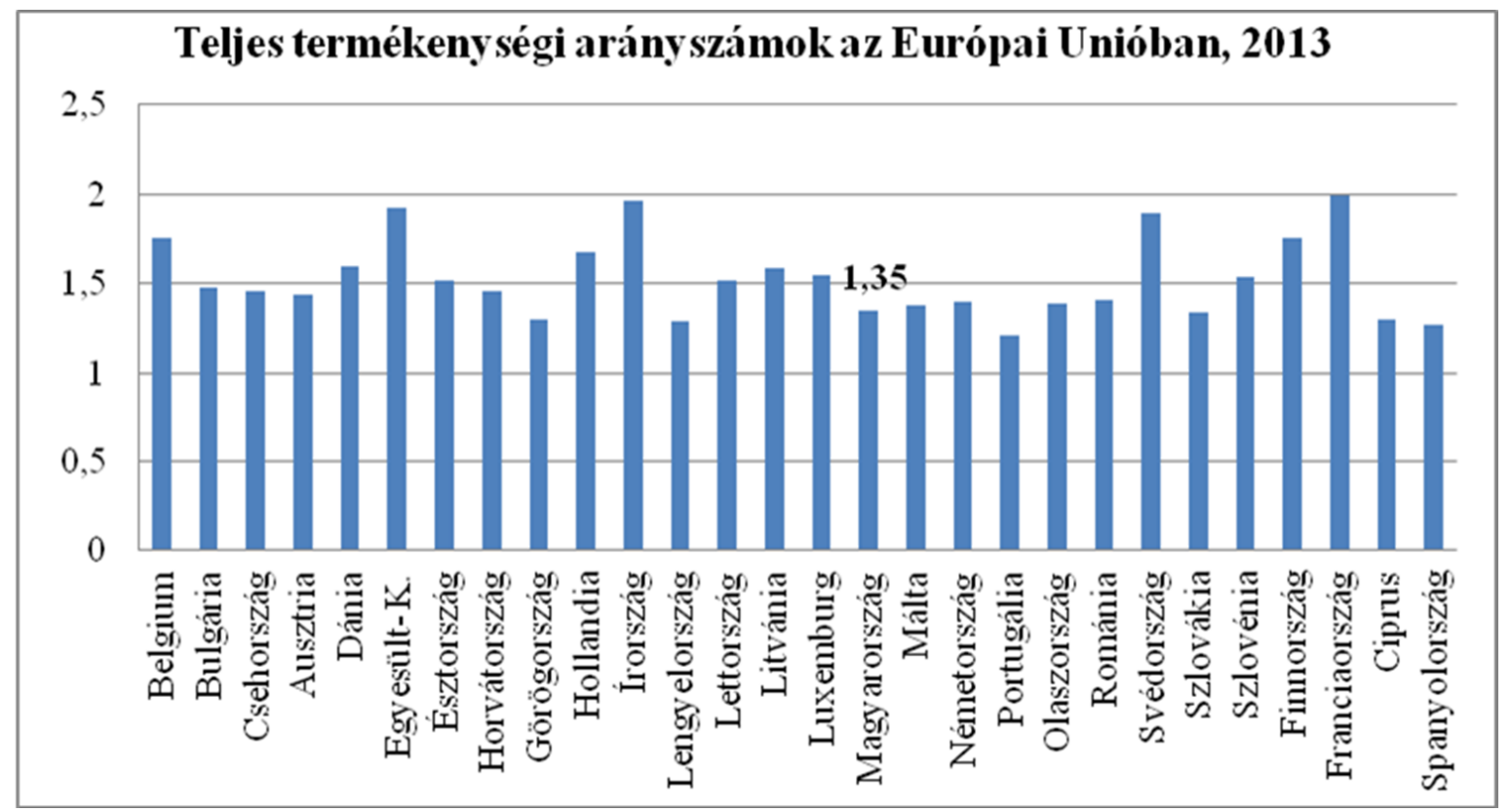

Forrás: Eurostat 2013. szerkesztett

Európában három termékenységi régiót különböztetnek meg a demográfusok. Ezek közül a legkedvezőbb helyzetben az észak és észak-nyugati országok vannak, esetükben nem jelentősek a termékenységi gondok, az átlagos gyermekszám 1,8 körül mozog (kivéve Luxemburgban, ahol 1,6) de Franciaországban és Írországban majdnem eléri a kettőt (Eurostat, 2013). A déli államokat az 1,4-es arányszám jellemzi, míg Közép-Európa mutatói a legrosszabbak (Kapitány és Spéder, 2009a).

Mi magyarázhatja a különbségeket, illetve milyen okok húzódnak a magyarországi igen alacsony gyermekvállalási hajlandóság mögött? A rendszerváltozást követő termékenységcsökkenés az egész régióban az első gyermeket vállaló nők életkorának emelkedésével hozható összefüggésbe. A korábban jellemző fiatalkori gyermekvállalási gyakorlat ma már nem jellemző, egyre több nő halasztja az első szülést a húszas évei végére (Spéder, 2006; Kapitány és Spéder, 2009a), vagy akár a harmincas évei elejére. Az elhalasztott termékenység pótlása több országban bekövetkezett, ennek köszönhetően Csehországban $(1,5)^{2}$, Bulgáriában $(1,48)^{3}$, Észtországban $(1,66)^{4}$ nőtt a gyerekek száma. Magyarország kivételnek számít, ugyanis a termékenységi mutatók javulásának semmilyen jele nem tapasztalható, annak ellenére, hogy a demográfusok azt remélték, hogy az 1975 körül született „Ratkó-unokák” harmincas éveik elején pótolni fogják a korábban elhalasztott gyermekvállalást. Azonban ez nem következett be. Az a korábban

\footnotetext{
2 2007. évi adat

${ }^{3}$ 2007. évi adat

${ }^{4}$ 2007. évi adat
} 
teljesen általános trend, mely szerint a nők húszas éveik első felében vállaltak gyermeket, mára már kifejezetten ritka. Ma már inkább az a jellemző, hogy rácsodálkozunk egy-egy a húszas évei elején járó anyukára, $\mathrm{s}$ teljesen általános jelenségként tekintünk a harminc körüli életkorra időzítette első gyermekvállalásra. Amíg 1990-ben a nők átlagosan 23 évesen szülték első gyermeküket, addig 2008ban a nők átlagos életkora első gyermekük születésekor közel 28 év volt (2. számú ábra). Ezt követően 2008 és 2011 között az első gyermek vállalásának időpontja még kis mértékben növekedett körülbelül 28,5 éves korig. Az egyes korosztályokat tekintve ez azt jelenti, hogy 2009-ben Magyarországon például a 30 éves nők 43\%a gyermektelen volt, s további 30\%-uk egygyermekes. Mindez azt mutatja, hogy Magyarországon lassan-lassan eltünik a '80-as évekre jellemző kétgyermekes családmodell, s egyre inkább egy olyan jövőkép rajzolódik ki, melyben a harmincas korosztály körében csökkenni fog a kétgyermekesek aránya, s ezzel párhuzamosan emelkedik majd a gyermektelenek és az egygyermekesek száma (Kapitány és Spéder, 2009a). A legfrissebb 2013-as hazai adatok azt mutatják, hogy az első gyermek vállalás halasztása megállt, sőt némileg csökkent (28,2 év) (Kapitány és Spéder, 2015).

\section{2. számú ábra}

A nök és a férfiak átlagos életkora gyermekük születésekor, 1990-2013

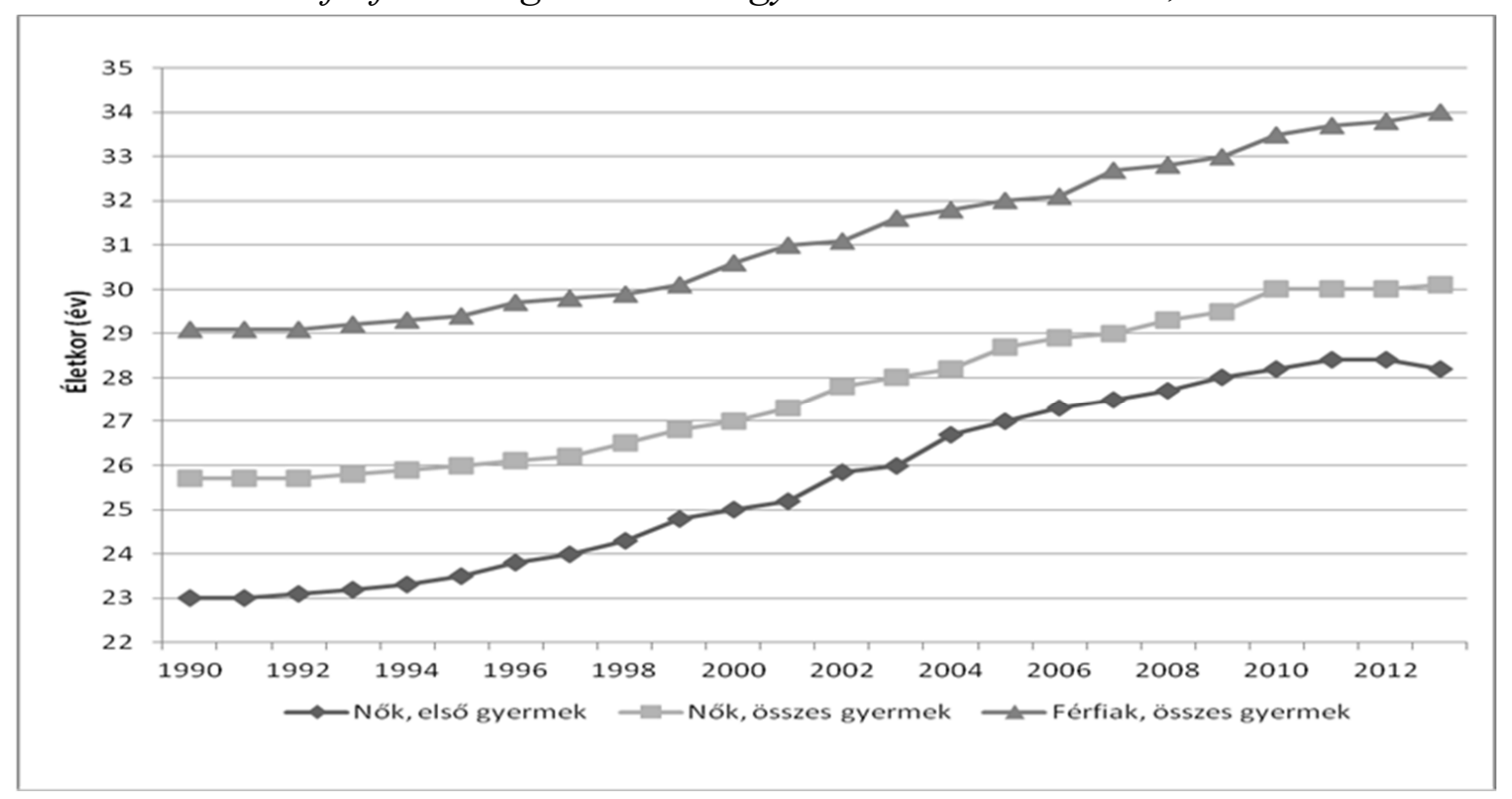

Forrás: Népmozgalmi adatok KSH-NKI; Kapitány és Spéder 2009a., 2015.

A gyermekvállalási kor kitolódásának a demográfiai következményeken túl lehet egy másik, nem kívánatos következménye, mégpedig a megszületett gyerek egészségének romlása. A 35 évnél idősebb nők körében történő szülések között „magasabb veszélyeztetettségi esélyek mutatkoznak”(Klinger, 2001:134). Ezt a nők 
életkora szerinti magzati veszteségek száma is alátámasztja, a 30-39 évesek körében a legmagasabb a korai-, a középidős és a késői magzati halálozás is (KSH, 2008).

A hazai kutatások egyértelmüen azt mutatják, hogy a népesség döntő többsége a gyermeket, a gyermekvállalást az ember életének legfontosabb momentumának tartja (Pongráczné, 2005). Azonban a gyermekvállalással kapcsolatos tervek megvalósulása akadályba ütközik. A tervezett és a realizált gyermekszám között kereken egy a különbség (Spéder, 2003). Magyarországon a családok többsége legalább két gyermekben gondolkodik, azonban 2002 és 2005 között a három éven belül gyermeket tervezők mindössze 29\%-a tudta valóra váltani ez irányú szándékait (Spéder és Kapitány, 2007; Makay, 2013, Kapitány és Spéder, 2015).

Több kutatás megerősíti azt az elképzelést, hogy a szándékok megvalósításánál jelentős szerepe van a családtámogatási eszközöknek és a foglalkoztatási helyzetnek. Az „Életünk fordulópontján” címü követéses vizsgálat érintettjei közül a nők 71\%a gondolta úgy, hogy a gyermekvállalás rontja munkahelyi kilátásaikat, s a férfiak 61\%-a ugyanígy gondolkodott a nők munkaerő-piaci lehetőségeiről. Sőt, a többség nem csak előre jelezte a veszélyt, de beszámoltak arról is, hogy gyermekvállalási döntéseik meghozatalakor kalkulálnak is a lehetséges munkaerő-piaci következményekkel (Kapitány és Spéder, 2009b). Abban, hogy ezek hogyan hatnak a gyermekvállalással kapcsolatos döntésekre, meghatározó jelentősége van a családtípusnak és annak, hogy a család (nő) mely társadalmi réteghez tartozik. A dolgozó és alacsony keresettel rendelkező nők az átlagnál nagyobb mértékben váltják valóra gyermekvállalási terveiket. Ez többek között a kedvező, jó helyettesítő értékkel bíró GYED-nek köszönhető. A magas jövedelmüek esetén viszont a GYED már nem váltja ki azt a haszonáldozatot, melyet a munkától való távolmaradás idéz elő. Az anyasági ellátásban részesülő, magas iskolai végzettségü, magas státusú nők azonban nagyobb eséllyel vállalnak további gyermeket. Lényegesen csökken a második és harmadik gyermekekre vonatkozó elképzelések valóra váltása, ha az anyasági ellátások kimerítése után megtörténik a munkaerőpiacra való visszatérés. Ez arra enged következtetni, hogy a munkaerőpiac és a családtámogatási rendszer okolható azért, hogy a közép szintü pozícióban lévő nők átlagos gyermekszáma a legalacsonyabb. A felsőbb társadalmi rétegeknél két ellentétes tendencia jelenik meg. Egyfelől nő a gyermektelenek és a többgyermekes nők aránya, másfelől az egygyermekeseké csökken. Összességében elmondható, hogy a munkaerőpiac mai mechanizmusai a gyermekvállalási tervek realizálása ellen hatnak, s ez leginkább az átlagos és a kevésbé iskolázott nők, második és további gyermekvállalási terveit érinti (Spéder és Kapitány, 2007). A gyermekvállalás halasztása és az iskolai végzettség között negatív kapcsolatot feltételez az „új háztartásökonómia” elmélet. Eszerint a magasabb iskolai végzettséggel rendelkező nők későbbre halasztják a 
családalapítást, és egyben kevesebb gyermeket vállalnak, mint kevésbé iskolázott társaik. Bár az egyértelműnek tủnik, hogy a magasabban kvalifikált nők nagyobb valószínúséggel odázzák el a családalapítást, azonban ennek oka inkább az oktatásban eltöltött időtartam növekedésével magyarázható, s nem az iskolázottsági szintben megjelenő különbségekkel. Az iskolai végzettség és gyermekszám kapcsolatát vizsgáló kutatások eredményei szerint azokban az országokban, ahol a közösségi politika családbarát, kevésbé általános tendencia, hogy a magasabb iskolázottság negatívan hatna a gyermekszámra (Husz, 2006; Spéder, 2006).

A fentebb említett hazai kutatások egyik fő megállapítása, hogy az alapvetően rendkívül gyermekbarát magyar társadalom realizált gyermekszáma elmarad a preferált gyermekszámhoz képest. Ennek elsődleges okaként a nehézkes munkaerőpiaci körülményeket említik. Ezt támasztja alá a külföldre vándorolt fiatalok - hazai viszonylatban - átlagot meghaladó gyermekszáma. A jövedelmi helyzet vagy talán inkább a jövedelmi biztonság és gyermekvállalás összefüggéseit erősíti az a sokat mondó tény, mely szerint a legtöbb volt szocialista országból kivándorlók gyermekvállalási hajlandósága jelentősen meghaladja a kibocsájtó országra általánosan jellemző értékeket. A 2011. évi népszámlálási adatok szerint az Angliában és Walesben élő magyar nők teljes termékenységi arányszáma (TTA) 1,63 volt, míg a Magyarországon élőké 1,24-es volt. Még hangsúlyosabb különbség mutatkozik meg a lengyel nők vonatkozásában: a lengyel nők TTA-ja odahaza 1,3 volt a vizsgált évben, míg az Angliában és Walesben élő társaké 2,13 (Kapitány és Spéder, 2015). A fentebb említett jövedelembiztonságon túl körvonalazódik e jelenség egy másik oka is, mely szerint a befogadó országra jellemző gyermekvállalási mintázat befolyással bír a bevándorló családok gyermekvállalási magatartására, ezt a magyarázatot erősíti a 2011-es népszámlálás brit és walesi nőkre vonatkoztatott 1,84-es TTA. A kivándorlás számos problémát vet fel, azonban témánk szempontjából a demográfiai veszteséget emeltük ki, mivel a kivándorlók jelentős többsége gyermekvállalási korban lévő fiatal.

\section{A fiatalok partnerkapcsolati jellemzői}

Az 1960-es évekig a nyugat-európai országokat egy általános érvényü párkapcsolati mintázattal jellemezhetjük (Makay, 2013). A házasság intézményét, mint egyetlen elfogadott párkapcsolati formát mindenki általános érvényünek tekintette, s a családalapítási szándék első lépcsőfokaként a húszas évek elején sor is került a házasságkötésre. A nyugat-európai országok mellett Magyarországon és a volt NDK-ban - eltérően a többi közép-kelet európai országtól - ehhez közeli időpontban, az 1970-es évektől kezdődött meg a házasságkötések számának a visszaesése. A legdrasztikusabb csökkenés 1990 és 2011 között tapasztalható hazai viszonylatban. A házasságkötésekben megfigyelhető csökkenő tendencia 2011-ben 
megállt, s azóta egy felfelé irányuló mozgás figyelhető meg (Statisztikai tükör, 2015). A népesség családi állapot szerinti megoszlásában is jelentős változások figyelhetők meg. 1990-ben a 15 évesnél idősebb korosztály 61\%-a házas volt, 2014ben már csak 42,9\%-a (KSH 2015).

A házasságkötések létszámbeli átalakulása mellett kezdetét vette a házasságkötési életkor kitolódása is. Amíg az 1980-as és 1990-es években a fiatalok áltagosan 20-24 évesen kötöttek házasságot, addigra 2011-ben a házasulandók mindössze 13\%-a esett ebben a korcsoportban. A legtöbb életét hivatalosan is összekötő fiatal a 25-29 évesekből került ki (30\%). Az ezt követő legnépesebb tábor a 30-34 éveseké volt (25\%) (KSH, 2011). Nemenkénti bontásban azt tapasztaljuk, hogy - hasonlóan az elmúlt évekhez - 2014-ben a nőknél a húszas éveik második fele, férfiaknál a 30-as éveik eleje volt a favorizált házasságkötési életkor (Statisztikai tükör, 2015). A „Magyar Ifjúság 2012” eredményei is a nemek eltérő időpontra időzített házasságkötési magatartását mutatja. A férfiaknál az tapasztalható, hogy 23 éves kor után kezd emelkedni a házasságkötések száma, azonban 29 éves korig a férfiak kevesebb, mint egynegyede kötött házasságot. A nőknél 21 éves az az életkori határ, ahol emelkedni kezd a házasságkötések száma, s a 29 évesek csoportján belül pedig már több mint 40\% a házasságban élők aránya. Összességében tehát megállapítható, hogy a fiatalok nagy része 15-29 éves kor között még nőtlen, illetve hajadon (Makay, 2013). Ennek egyik (talán legmeghatározóbb) oka, hogy a házasság már nem az egyetlen legitim családforma, az élettársi kapcsolatot preferálók aránya egyre nagyobb. Ez a párkapcsolati forma a korábbiakkal ellentétben már nemcsak az alacsony iskolai végzettséggel bírók csoportjához köthető, hanem a nőtlen, illetve a hajadon fiatalokhoz is, akiknek egy jelentős része a házasságkötés előszobájaként tekint erre a párkapcsolati formulára. Meg kell említeni, hogy az elvált, újra tartós kapcsolatot létesítők körében is igen jellemző az élettársi kapcsolat (Makay, 2013).

\section{A fiatalok véleménye a párválasztásról és gyermekvállalásról}

A Nyíregyházán élö fiatalokon belül a 15-18 éves korcsoporthoz tartozók nagyobb része úgy nyilatkozott, hogy nincs most jelenleg barátja/barátnője, mindemellett közel 60\%-uk válaszolta azt, hogy volt már korábban kapcsolata. A 18 év alatti fiúk közel 60\%-ának volt már barátnője és jelenleg egyharmaduknak van is kapcsolata. A hasonló korú lányoknál azt tapasztaltuk, hogy 55\%-uknak volt már partnere, s 39\%-uk jelenleg is ,jár”. Nagyon kevesen számoltak be arról, hogy a megkérdezés pillanatában együtt élnének párjukkal, mindössze $0,8 \%$-uk válaszolt erre a kérdésre igennel. Ez teljesen egyértelmünek tünik, hiszen ezeknek a fiataloknak a többsége minden bizonnyal még valamelyik köznevelési intézményben tanul. Ehhez hasonló eredményre jutottak a „Magyar Ifjúság 2012” kutatói is. Az tapasztalták, hogy az 
összeköltözés általában 23 és 24 éves kor környékén ugrik meg hirtelen, vélhetően a tanulmányok befejezésének következtében (Makay, 2013).

A 19-29 évesek közül 10\% házas, 4,5\% élettársi kapcsolatban él párjával, 75\%uk a nőtlenek, hajadonok közé sorolta magát, 2 fö elváltként nyilatkozott saját helyzetéről, 1 fö pedig özvegy volt a megkérdezés pillanatában. A nőtlen és hajadon státusú 19-29 éves fiatalok körében közel fele arányban vannak azok, akik együtt élnek jelenlegi partnerükkel. (A fentebb leírt összefüggéseket és a két korcsoportnál észlelt különbségeket az életkori hatással magyarázzuk.) A 18 éven felüliek almintáját vizsgálva megállapíthatjuk, hogy a 18. életévtől kezdődően kezd el emelkedni az első élettársi kapcsolatot létesítők aránya, ennél jelentősebb emelkedés húsz éves kortól figyelhető meg. Az első élettársi kapcsolatlétesítés 53\%-a 20-26 éves kor közé esett, a házasságkötés időpontjára kérdezve a 25 évesek csoportja jelent meg a legnagyobb súllyal. Az átlagos házasságkötési életkor 24,3 év volt a 1929 éveseknél. Nemenkénti bontásban azt találtuk, hogy a férfiak és nők átlagos házasságkötési kora között szinte pontosan egy év a különbség. A nyíregyházi fiatalok közül a legkorábban frigyre lépö 18 éves (1 fö), a legkésőbben házasodó pedig 28 éves volt (3 fó).

\section{Vélemények a házasságról}

A nem házas válaszadó fiatalok jelentős többsége (67\%) házasként képzeli el a jövőjét. A határozott biztos, hogy szeretne házasságot kötni kijelentés mellett érvelők aránya $47 \%$, az inkább igenre szavazók a minta egynegyedére volt jellemzö, az inkább nemmel válaszolók mindössze $11 \%$-ot tettek ki és ennél is alacsonyabb volt a házasság intézményét egyértelmüen elutasítók aránya (7,5\%). A két korcsoport véleményét külön vizsgálva egyetlen esetben tapasztalunk jelentős eltérést. Meglepő módon a 15-18 éves korosztály sokkal határozottabban kiáll a házasságkötés fontossága mellett. Párkapcsolati preferenciájuk mintázata ezt tükrözi. E fiatal korosztályban igen magas, 54\% azok aránya, akik a Szeretne-e házasságban élni? kérdésre, a biztos igen válaszlehetőséget jelölte meg (a 19-29 éveseknél ez az arány 44\%). Az inkább igen válaszlehetőséggel a 15-18 éves korosztály 19\% élt (a 19-29 éveseknél ez az arány 21\%). Ez azért meglepő, mert a „Magyar Ifjúság 2012” adatai szerint éppen a fiatalabbakra jellemző a bizonytalan, hezitáló álláspont.

Nemenkénti bontásban vizsgálódva látható, hogy a megkérdezés időpontjában még nem házas nők és férfiak meghatározó többsége azonosul a házasság intézményével. Különbség inkább a házasságkötési attitüdbeli határozottságban lehető fel. Amíg a nők fele, addig a férfiak 43\%-a válaszolta azt, hogy biztos, hogy szeretne házasodni a jövőben. S a hezitáló álláspont (,nem tudja”) is jellemzőbb a férfiakra, mint a nőkre. 
Az iskolai végzettség és a házasságkötési attitüd összefüggéseit vizsgálva azt tapasztaltuk, hogy az egyes iskolai végzettség szerinti csoportokon belül a ,, biztosan nem kötne házasságot" válaszlehetőség elfogadása a mesterképzésben végzettek, valamint a szakmunkásképzőt, szakiskolát végzettek körében volt a legmagasabb. A házasságkötési szándék egyértelmü kifejezése (,,biztos igen” válasz) pedig a gimnáziumi érettségivel rendelkezőket jellemezte a leginkább.

A munkaerö-piaci pozíció és a házasságkötési hajlandóság közötti kapcsolatra pedig a következő a jellemző: a megkérdezés idején fizetett munkát végzők és nem végzők 16\% - 16\%-a biztosan nem vagy inkább nem kíván házasságot kötni. A házasság intézményével teljes mértékben szimpatizál (biztos igennel válaszolt) a fizetett munkát végzők 43\%-a. A munka világától távol lévők esetében ez az arány $51 \%$.

\section{1. számú táblázat}

Ha ön jelenleg nem házas, szeretne-e házasságban élni a közeli, akár a távoli jövőben?(\%) $N=249,348$

\begin{tabular}{|c|c|c|}
\hline & férfiak & nők \\
\hline biztosan igen & 43 & 50,1 \\
\hline inkább igen & 20,9 & 19,2 \\
\hline inkább nem & 11,6 & 10,1 \\
\hline biztosan nem & 8 & 6,7 \\
\hline \hline nem tudja & 16,5 & 13,9 \\
\hline
\end{tabular}

Forrás: Nyíregyházi Ifjúsága kutatás 2015. szerkesztett

\section{Házassággal szembeni érvek}

A házassági életformát elutasítóknak lehetősége volt arra, hogy tíz érvet értékeljenek annak megfelelően, hogy ezek mennyire tartják vissza öket a házasságkötéstöl. Nemenkénti bontásban azt láttuk, hogy a férfiak és nők állításstruktúrája nem különbözött egymástól releváns módon. Mindkét nem a következő három érvet fogadta el az áltagosnál nagyobb arányban: „még túl fiatal ehhez” a nők 48\%-át, a férfiak 41\%-át ez a tény tartja leginkább vissza a házasságkötéstől. A nők szinte ugyanilyen arányban (49\%) gondolták úgy, hogy „előbb be akarja fejezni a tanulmányait”, a férfiak körében ennek az állításnak az elfogadása valamivel kisebb kört érintett (35\%). A harmadik leginkább visszatartó tényező a „,még nem biztos, hogy megtalálta az igazit" érv volt (nők 42\%, férfiak 40\%). Meglátásunk szerint a fent említett, a házasság elutasításához kapcsolt hármas érvrendszer nem jelenti egyértelműen e családforma végleges elutasítását, hiszen mindhárom esetben egy viszonylag gyorsan változó, külső körülményről van szó. Az életkor, a tanulmányok 
befejezése mindenféle külső beavatkozás nélkül az idő múlásával megszünik, mint akadályozó tényező. Az ,igazi” hiánya pedig vélhetően épp az első kettő (vagyis a fiatal életkor) eredője. Továbbá, a „még nem biztos, hogy megtalálta az igazit” érv arra is utalhat, hogy rátalálva a potenciális partnerre már ez a házassággal szembeni ellenérv is érvényét veszíti. Érdemes megemlíteni, hogy a „Magyar Ifjúság 2012” országos adatfelvételében a „hiányoznak hozzá az anyagiak”, a „még nem biztos, hogy megtalálta az igazit” és a „túl sok költséget jelent” állítások voltak a legtöbbek által elfogadott érvek.

\section{Érvek a házasság mellett}

A házasságról alkotott elképzelést sok tényező befolyásolhatja, például egy-egy családon belüli jó vagy rossz példa, vagy az elvárásoknak való megfelelés, vagy akár az is, hogy mit közvetít a média. Tanulmányunkban a média szerepével nem foglalkozunk, azonban a kötet egy tanulmánya (Huszti és Takács, 2006) részletesen elemzi a média ifjúságra gyakorolt hatását. Azonban a házasságkötést meghatározó egyéb magyarázó tényezőket megpróbáljuk feltérképezni. Arra kértük a fiatalokat, hogy a felsorolt állításokat osztályozzák annak megfelelöen, hogy mennyire jellemzik azok a házasságkötésről való gondolkodásukat, például „Azért kötne házasságot, mert a környezete (a társadalom) elvárja”. A megkérdezettek a következő állításokat értékelték 4-essel, illetve 5-össel (az ötfokú skálán), tehát teljes mértékben egyetértettek, illetve egyetértettek az adott állítással. Sorrendben a legnagyobb elfogadottsága: „az együttélés legjobb/legtermészetesebb módja” kijelentésnek volt, válaszadó fiatalok 74\%-a mondta azt, hogy teljesen egyetért, illetve egyetért ezzel. A második a rangsorban az „erösebb párkapcsolati köteléket jelent" állítást, a fiatalok 72\%-a értékelte 4-essel, illetve 5-össel, és $16 \%$ gondolta azt, hogy rá ez nem, vagy egyáltalán nem jellemző. A harmadikként legtöbbek által elfogadott állitás :,, a gyermek számára ez a legjobb" volt, mellyel a fiatalok 57\%-a értett egyet vagy értett egyet teljes mértékben, s egynegyedük nyilatkozott úgy, hogy egyáltalán nem vagy nem ért egyet ezzel az állítással.

A válaszadók véleményéből egy erősnek mondható tradicionális attitüd tükröződik vissza, mely szerint a házasság intézménye fontos az érintettek számára.

\section{Gyermekszám preferenciák}

A magyar társadalomra alapvetően egy igen gyermekcentrikus attitüd jellemzö, a gyermekvállalási aspirációkat körbejáró vizsgálatokból (például Spéder, 2006; Kapitány és Spéder, 2015) ez egyértelmüen kiderült. Ehhez kapcsolódóan azt vizsgáljuk, hogy a 15-18 és a 19-29 évesek hogyan gondolkodnak az ideális gyermekszámról. Akik már rendelkeznek gyermekkel azok szeretnének-e még többet vállalni, s milyen életkorba tervezik a gyermekvállalási tervek realizálását? S 
vajon jellemzi-e a Nyíregyházán élö fiatalokat az akaratlagos gyermektelenség elfogadása?

A fiatalabb almintára vonatkozóan a gyermekvállalási tervekről kérdeztük a 1518 éveseket, míg a 19-29 éveseknél a már meglévő, illetve a későbbikre tervezett gyermekszámról is információhoz jutottunk.

A 15-18 évesek a két gyermeket tekintik a legideálisabbnak, majd 50\%-uk terveik szerint kétgyermekes családban él majd. A második preferált gyermekszám a három volt, erről a fiatalok 18\%-a vallott. Érdekesnek tünhet, hogy a „nem tudom” válaszlehetőséget most kiemelten kezeljük. Részben azért mert viszonylag magas azoknak az aránya, akik nem tudják még erre a kérdésre a választ $(14 \%)^{5}$ vagy nem is válaszoltak, részben pedig azért, mert valahol természetesnek vehetjük, hogy ebben a korcsoportban, föleg a legfiatalabbak esetében ez az esemény még olyan távolinak tünik, hogy még megjósolni sem tudják, hogyan képzelik el magukat szülöként. A bizonytalanok körében magasabb a férfiak száma. Egy gyermekben gondolkodik 11,6\%-uk és 4 vagy több gyermeket tart ideálisnak 3\%-uk és közel ennyien nem szeretnének gyermeket.

\section{3. számú ábra}

Összesen hány gyermeket szeretne? 15-18 évesek, (\%), $N=207$

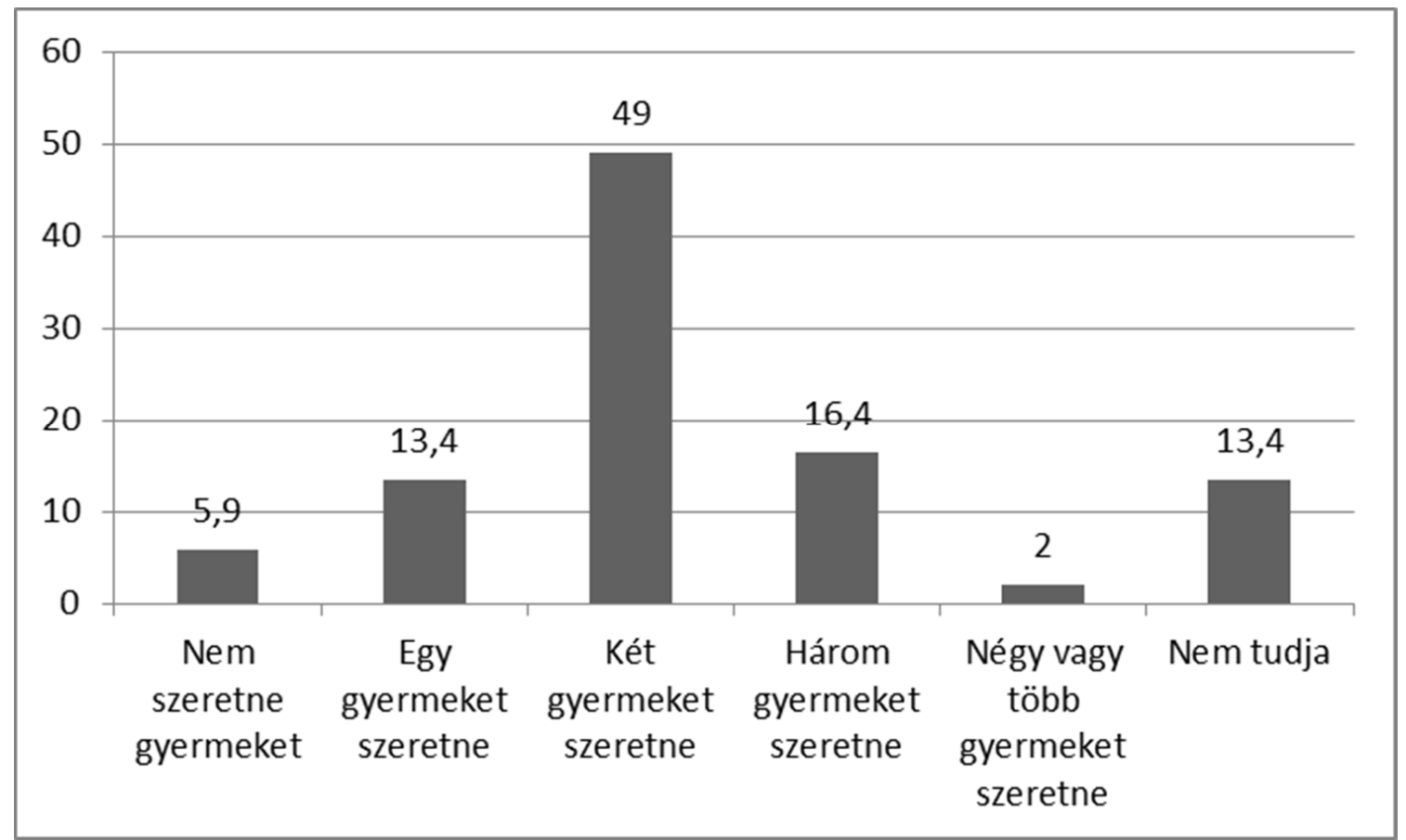

Forrás: Nyíregyházi Ifjúsága kutatás 2015. szerkesztett

\footnotetext{
5 Nagy a valószínűsége annak, hogy egyéb kérdéscsoportok válaszadási hajlandósága magasabb már csak az életkori sajátosságok miatt is. Feltételezhető, hogy például a szabadidő eltöltéséröl - melynek részletes elemzésével Kovács Klára (2016) foglalkozik - szívesebben nyilatkozik a fiatalabb alminta.
} 
Korábban már megemlítettük, hogy a gyermekvállalás életkora kitolódott, s ma már a nők inkább a harmincas éveikhez közel vállalják az első gyermeküket. A 15-18 éveseknek ezzel összefüggésben arra kellett válaszolniuk, hogyan tervezik, hány éves korukban szeretnének gyermeket vállalni? A 4. számú ábrán jól látható, hogy igen kevesen, mindössze a válaszadók 1,4\%-a gondolta úgy, húszéves koránál hamarabb kíván gyermeket vállalni. Ennél jóval többen közel 27\% prognosztizálta ezt az eseményt 20 és 24 éves kora közé. A legnépesebb csoportot a 25-29 éves kort ideálisnak tekintők alkotják (49\%), ezen belül is a legtöbben (több mint 20\%) a 25 . életévet jelölték meg. A megkérdezettek 10\%-a véli úgy, hogy a harmincas évek a legoptimálisabbak a gyermekvállalásra, s ennél valamivel többen még bizonytalanok a kérdést illetően (13\%).

\section{4. számú ábra}

Hány éves korában szeretné, hogy az elsö gyermeke megszülessen? 15-18 évesek (\%), $N=210$

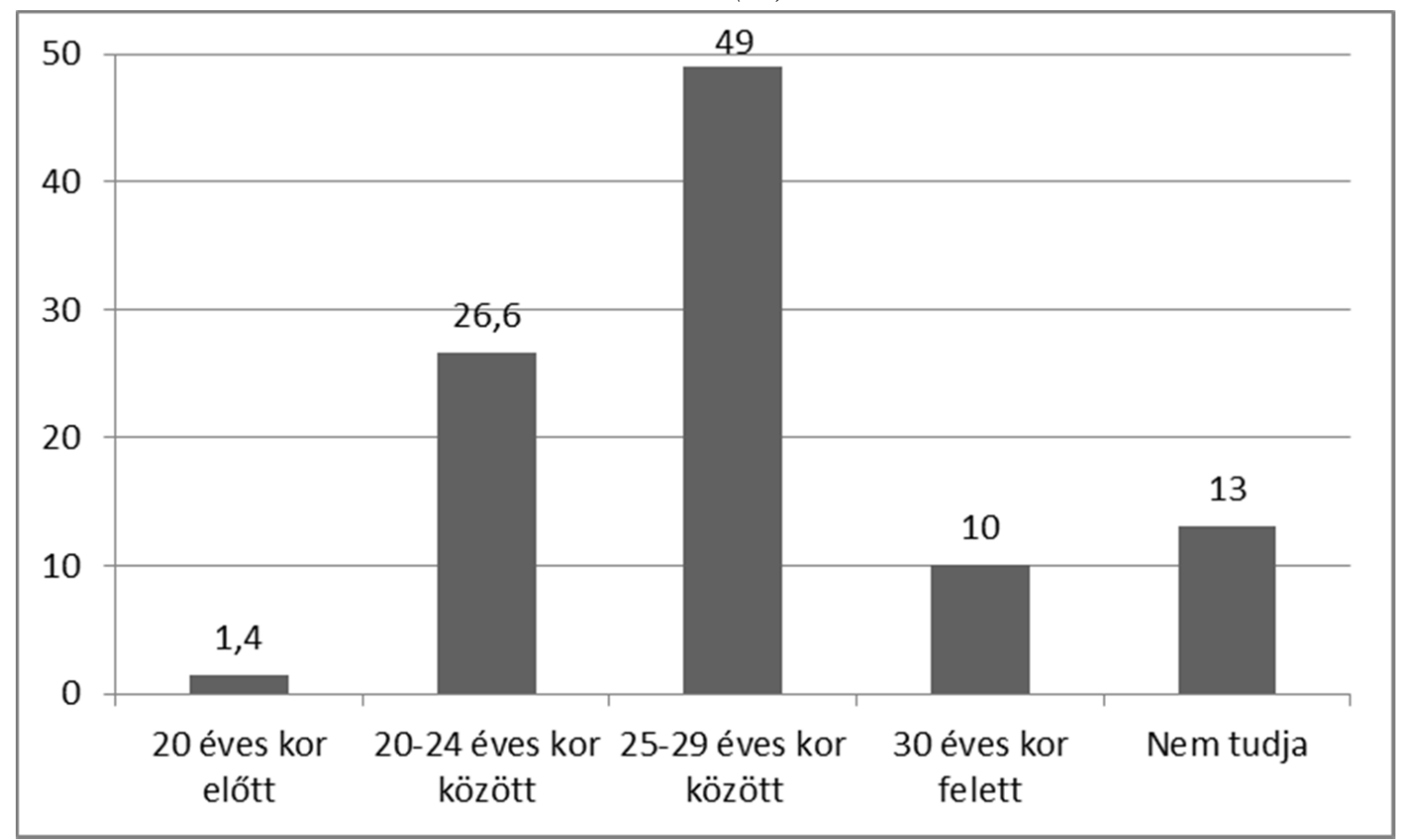

Forrás: Nyíregyházi Ifjúsága kutatás 2015. szerkesztett

A 19-29 évesek gyermekvállalási profiljáról a következő mondható el: a megkérdezettek több mint fele nyilatkozta azt, hogy ,nincs gyermeke, illetve most várja az elsőt" kategóriába sorolta magát. Egy gyermeket nevel a megkérdezettek 15\%-a, két gyermeke van a válaszadók 4,7\%-nak és három vagy több gyermekes családban él 2,8\%-uk. A gyermekvállalási életkort tekintve megállapíthatjuk, hogy a legfiatalabban gyermeket vállaló 16 éves volt (1 fö), a legidősebb pedig 28 éves ( 3 fö). A legtöbben (52\%) 22 és 28 éves koruk között váltak szülővé először. A férfiak átlagosan 24 évesek voltak első gyermekük születésénél, a nők pedig 22 évesek. 
5. számú ábra

Gyermekszám a 19-29 évesek körében, (\%), $N=342$

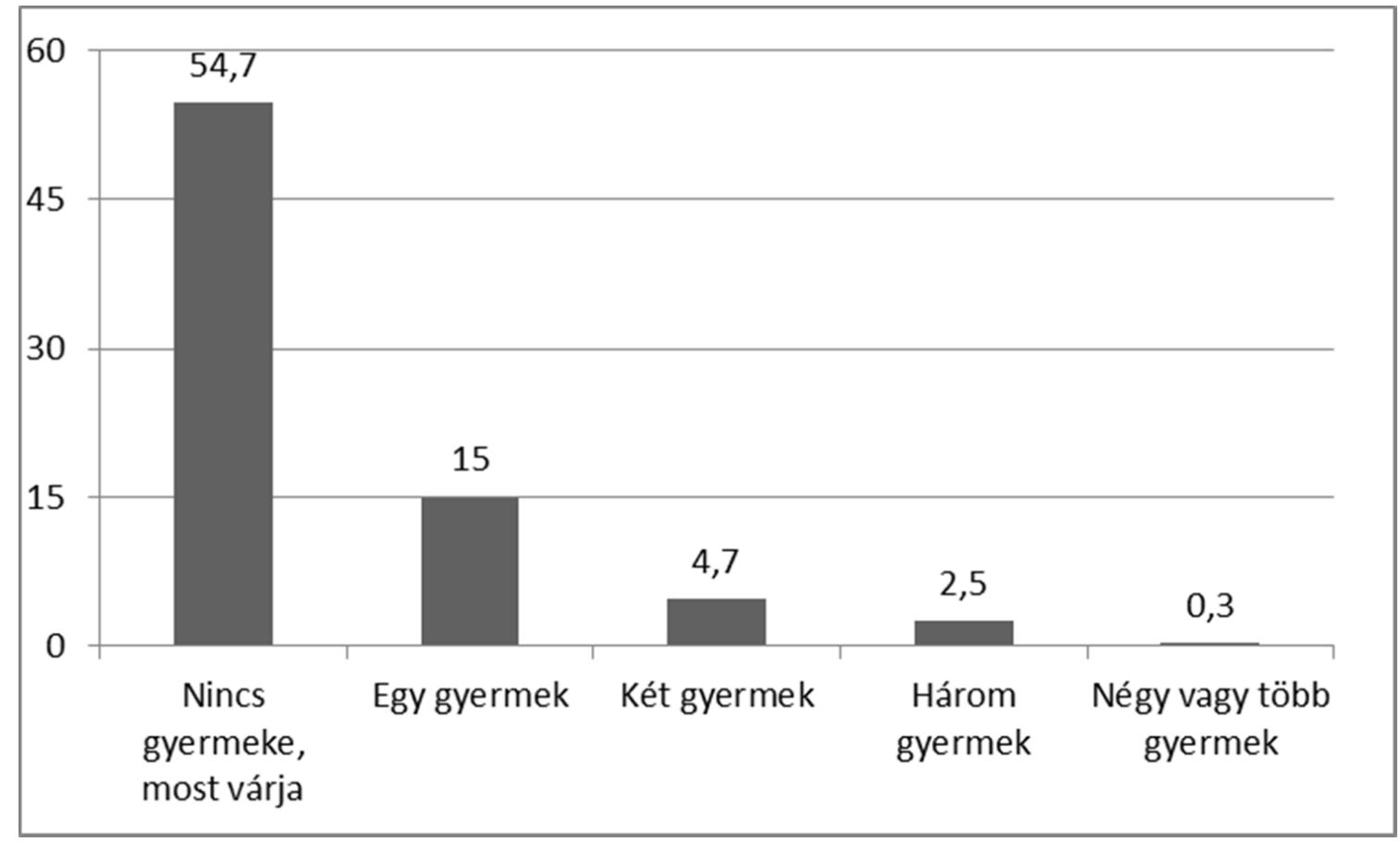

Forrás: Nyíregyházi Ifjúsága kutatás 2015. szerkesztett

Arra a kérdésre, hogy miért nem vállalt fiatalabban gyermeket a következő válaszok voltak a leggyakrabban említettek (az említések gyakoriságának sorrendjében): túl fiatal még; anyagi okok; tanulni szeretne még'; egyszerüen nem akar még gyermeket; lakhatási nehézségek; munka, karrier miatt; nincs partnere; a gyermekneveléssel járó többlet feladatok miatt; partner nem akar; egészségügyi okok.

A 19-29 évesekről a gyermekszám preferenciákat tekintve elmondhatjuk, hogy a többség a '80-as évek egyeduralkodó kétgyermekes családmodelljét tekinti ideálisnak (49\%). Az egy gyermekben és egyelöre nem tudja még, hogy hányban gondolkozik, 13,4-13,4\%. A három vagy több gyermek vállalását a válaszadók 18\%a preferálja, és 6\% nem szeretne gyermeket. Ez utóbbi csoport aránya a teljes mintában 5\%. Ez közel azonos az országosan mért önként vállalt gyermektelenek arányával $(6 \%)$.

\footnotetext{
${ }^{6}$ A 19-29 éves korosztályba tartozók egyharmada (a férfiak 32,4, a nők 38,5 százaléka tervez további tanulmányokat - ez csak részben magyarázhatja meg a korosztály gyermekvállalási szándékát és terveit (lásd: Fónai - Szigeti tanulmányát e kötetben).
} 


\section{6. számú ábra}

Összesen hány gyermeket szeretne? 19-29 évesek, (\%), $N=409$

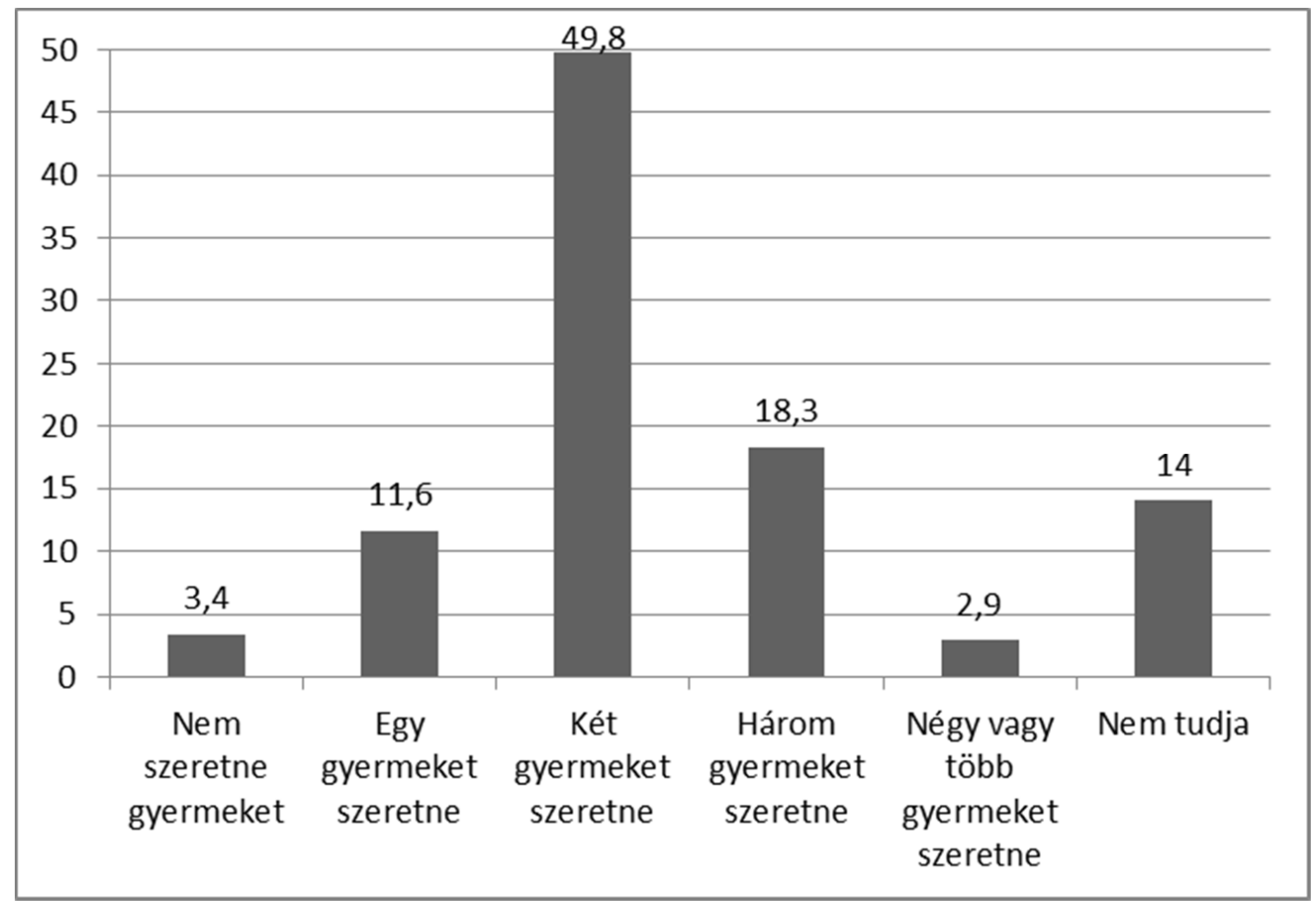

Forrás: Nyíregyházi Ifjúsága kutatás 2015. szerkesztett

A magyar társadalomra kevésbé jellemző a gyermektelenséget önként vállaló attitüd, azonban az egyéb, például egészségügyi okokra visszavezethető gyermektelenség esetén a pároknak lehetőségük van arra, hogy különböző alternatívák közül válasszanak a kívánt gyermekáldás realizálása érdekében. Ehhez kapcsolódóan arra kellett válaszolniuk a 15-29 éves korosztálynak, hogy ha valamilyen oknál fogva nehezített lenne a gyermekvállalás, élnének-e a felsorolt alternatívák valamelyikével. A teljes mintát egyben kezelve azt tapasztaltuk, hogy általában véve nyitottak lennének a meddőség elleni kezelés, mesterséges megtermékenyítés, örökbefogadás alternatívákra, azonban a béranyaság és egy másik lehetséges partnerben való gondolkodás vonatkozásában elutasító vélemények fogalmazódtak meg. A fiatalabb korosztály egyértelműen elutasítja a béranyaságot (90\%), és leginkább az örökbefogadást tartják jónak (60\%). A 19-29 éves korosztály véleménynyilvánítása szerint a háromnegyedük igénybe venné a meddőség elleni kezelést és a mesterséges megtermékenyítést, a béranyaságra viszont csak $16 \%$-uk tekint alternatívaként, az örökbefogadást pedig szinte ugyanannyian választanák, mint ahányan elutasítják. A másik partner választását szintén kevesen tartanák jó megoldásnak. 


\section{Összegzés}

Írásunkban a Nyíregyházán élő fiatalok (15-29 év) párválasztásához, gyermekvállaláshoz füződő attitüdjét térképeztük fel. A véleménynyilvánítások egy gyermekcentrikus és házasságpárti helyi fiatal társadalom jelenlétéről árulkodnak.

Eredményeink szerint a többség a kétgyermekes családmodellt preferálja. A második legtöbbek által ideálisnak tartott gyermekszám a három, majd harmadikként az egy gyermekben gondolkodók következnek. Kevesen, a válaszadók mindössze 5\%-a nem szeretne gyermeket vállalni.

A 19-29 éves korosztály többségének (55\%) a megkérdezés pillanatában még nem volt gyermeke. A gyermekesek közül a legtöbben egyelöre egy gyermeket nevelnek, de - mint ahogyan azt említettük - mind a 15-18 évesek, mind pedig a 1929 évesek csoportján belül a legtöbben két gyermekben gondolkodnak a későbbiekben. A 15-18 évesek közel fele úgy tervezi, hogy 25-29 éves kora között vállalja az első gyermekét, az ezt követő legnépesebb csoport azoké volt, akik 20-24 éves korukra időzítenék ezt az eseményt.

A jelenleg független fiatalok meghatározó többsége házasként képzeli el a jövőjét. A férfiak $64 \%$-a, a nők $69 \%$-a szeretne házasságot kötni a jövőben. A házasság intézményét nem preferálókat a következő érvek tartják vissza a házasságkötéstől: „még túl fiatal ehhez”, „előbb be akarja fejezni a tanulmányait”, „még nem biztos, hogy megtalálta az igazit”.

\section{Felhasznált irodalom}

1.) Fónai Mihály, Szigeti Fruzsina (2016): A nyíregyházán tanuló fiatalok képzettsége és oktatással kapcsolatos tervei. In: Acta Medicinae et Sociologica Vol. 7. No. 30-49. oldal

2.) Husz Ildikó (2006): Iskolázottság és gyermekvállalás időzítése. Demográfia 49/1, 4667.

3.) Huszti Éva, Takács Péter (2016): Médiahasználat a nyíregyházi ifjúság (15-29 évesek) körében. Új eszközök - új generáció? In: Acta Medicinae et Sociologica Vol. 7. No. 82-111. oldal

4.) Kapitány Balázs, Spéder Zsolt (2009a): Gyermekvállalás In: Monostori Judit, Öri Péter, S. Molnár Edit, Spéder Zsolt (szerk.): Demográfiai Portré. Jelentés a magyar népesség helyzetérő. KSH. Népességtudományi Kutató Intézet, Budapest, 29-40.

5.) Kapitány Balázs, Spéder Zsolt (2009b): A munkaerőpiac és a pénzbeli családtámogatási rendszer hatása a gyermekvállalási tervek megvalósulására tükrében In: Nagy Ildikó, Pongrácz Tiborné (szerk.): Szerepváltozások. Jelentés a nök és férfiak helyzetéröl. Szociális és Munkaügyi Minisztérium. TÁRKI, Budapest, 79-94.

6.) Kapitány Balázs, Spéder Zsolt (2015): Gyermekvállalás. In. Monostori Judit, Öri Péter, Spéder Zsolt (szerk): Demográfiai portré. KSH Népességtudományi Kutatóintézet, Budapest. 
7.) Klinger András (2001): A késői gyermekvállalás problémái. In: Nagy Ildikó, Pongrácz Tiborné, Tóth István György (szerk.): Szerepváltozások. Jelentés a nök és férfiak helyzetéről. Szociális és Családügyi Minisztérium Nőképviseleti Titkárság. TÁRKI, Budapest, 134-154.

8.) Kovács Klára (2016): Szabadidö-eltöltés és sportolás a nyíregyházi fiatalok körében. In: Acta Medicinae et Sociologica Vol. 7. No. 112-130. oldal

9.) KSH (2008): Középpontban a nők. Statisztikai Tükör II. évfolyam, 15. szám.

10.) Makay Zsuzsanna (2013): Párkapcsolati magatartás és gyermekvállalás a fiatalok körében. In. Magyar Ifjúság 2012.

11.) Pongrácz Tiborné (2005): A család és a munka szerepe a nők életében In: Nagy Ildikó, Pongrácz Tiborné, Tóth István György (szerk.): Szerepváltozások. Jelentés a nők és a férfiak helyzetérő. TÁRKI Ifjúsági, Családügyi, Szociális és Esélyegyenlőségi Minisztérium, Budapest, 73-86.

12.) R. Fedor Anita (2015): Egyensúlyban? A munkaerő-piaci karriertől a familiarizmusig. Debrecen: Debreceni Egyetemi Kiadó, 2015. 252 p.

13.) Spéder Zsolt (2003): Gyermeket vállalni új strukturális körülmények között In: Spéder Zsolt (szerk.): Család és népesség itthon és Európában. KSH NKI-Századvég, Budapest, 86-112.

14.) Spéder Zsolt (2006): Mintaváltás közben. A gyermekvállalás időzítése az életútban, különös tekintettel a szülő nők iskolai végzettségére és a párkapcsolati státusára. Demográfia. 49/2-3, 113-148.

15.) Spéder Zsolt, Kapitány Balázs (2007): Gyermekek: vágyak és tények. Dinamikus termékenységi elemzések. Életünk fordulópontjai, Mühelytanulmányok. 6. KSH-NKI, Budapest.

16.) Van de Kaa, D. J. (1987): Europe's second demographic transition. Population Bulletin $42 / 1,1-49$

\section{Felhasznált adatbázisok}

Eurostat (2013):

http://ec.europa.eu/eurostat/statistics-explained/index.php/Fertility_statistics

KSH(2011): ttps://www.ksh.hu/docs/hun/xstadat/xstadat_eves/i_wdsd002.html

KSH (2015): https://www.ksh.hu/docs/hun/xstadat/xstadat_eves/i_wnt001b.html

Statisztikai tükör (2015):

Rusinné Dr. Fedor Anita szociológus, szociálpolitikus, főiskolai docens. Debreceni Egyetem Egészségügyi Kar Szociális és Társadalomtudományi Intézet. e-mail: fedor.anita@foh.unideb.hu 